\title{
Numbers of spermatozoa in queens and drones indicate multiple mating of queens in Apis andreniformis and Apis dorsata
}

\author{
G Koeniger ${ }^{1^{*}}, \mathrm{~N}$ Koeniger ${ }^{1}, \mathrm{M}$ Mardan 2 , \\ RWK Punchihewa ${ }^{3}$, GW Otis ${ }^{2}$ \\ 1 Institut für Bienenkunde, Polytechnische Gesellschaft; FB Biologie \\ an der JW Goethe-Universität, Frankfurt, $K-v-$ Frisch-Weg 2, D-6370 Oberursel, FRG; \\ 2 Universiti Pertanian Malaysia, Department of Plant Protection, \\ 43400 Serdang, Selangor, Malaysia; \\ ${ }^{3}$ Sri Lanka Department of Agriculture, Agriculture Research Station, \\ Makandura, Gonawila (NWP), Sri Lanka
}

(Received 24 November 1989; accepted 3 May 1990)

\begin{abstract}
Summary - Drones of Apis dorsata had an average of $2.46 \cdot 10^{6}$ spermatozoa in their vesiculae seminales. Two queens had $3.67 \cdot 10^{6}$ spermatozoa in their spermathecae. In $A$ adreniformis, drones had an average of $0.13 \cdot 10^{6}$ and the spermathecae of 2 queens contained 0.98 and $1.09 \cdot 10^{6}$ spermatozoa. In both $A$ dorsata and $A$ andreniformis the spermathecae of queens contained more spermatozoa than the vesiculae seminales of a single drone of either species. Therefore, we conclude that multiple mating occurs in both species as is the case for $A$ mellifera, $A$ cerana and $A$ florea.
\end{abstract}

multiple mating / spermatozoon / Apis andreniformis / Apis dorsata

\section{INTRODUCTION}

In the past, sperm counts in drones and queens have provided valuable information on mating behavior. The high numbers of spermatozoa in the oviducts of freshly mated queens relative to the numbers in mature drones indicate that queens of $\boldsymbol{A}$ mellifera and $A$ cerana are mated by an average of 8-10 drones on 1 mating flight (Tryasko, 1956; Woyke, 1960, 1975).

The numbers of spermatozoa in males and in spermathecae of queens have barely been studied in other species. Recently, in $A$ florea, sperm counts of freshly mated queens revealed that, in this species, sperm is not injected into the oviducts but directly into the spermatheca. Drones only have about $1 / 3$ as many spermatozoa in the vesiculae seminales as are contained in the spermatheca of the queen, suggesting that queens mate with 2-3 males (Koeniger et al, 1989).

In this paper we report numbers of spermatozoa of queens and drones of $A$ andreniformis and $A$ dorsata. Furthermore, the size of the spermathecae was

\footnotetext{
* Correspondence and reprints
} 
measured and the number of ovarioles was counted.

\section{MATERIAL AND METHODS}

Samples of $A$ andreniformis were collected in the Johore state, Malaysia. $A$ dorsata drones were collected in the Selangor state, Malaysia and queens in the Anuradhapura district, Sri Lanka.

Drones were kept for some hours without food until they were too weak to empty the vesiculae seminales when killed by ether. Afterwards the drones were dissected and the vesiculae seminales were isolated. Drones were considered to be sexually mature when the testis had become degenerate and when the cornua had an orange color.

Queens were dissected and the spermatheca isolated. After removal of the tracheal net, the diameter of the globular spermatheca was measured under a microscope.

In each case, the organs were transferred into $1 \mathrm{ml} 0.9 \% \mathrm{NaCl}$ in order to count the spermatozoa. The organ was ruptured with fine forceps and the emerging spermatozoa were dispersed evenly in the fluid by heavily blowing air through it with a syringe. If the sperm concentration was high (opaque fluid), the sample was further diluted with up to $9 \mathrm{ml}$ of distilled water.

A haemocytometer (Fuchs-Rosenthal or the "improved Neubauer") was used to count the sperm.

The fresh ovaries were isolated and divided into 4 portions; the number of ovarioles counted ranged between 10 to 30 per portion. Then $70 \%$ ethanol was poured over it; thus, the ovarioles became white and were easy to count.

\section{RESULTS}

\section{Vesiculae seminales}

In drones of $A$ andreniformis $(n=5)$, the average number of spermatozoa in the vesiculae seminales was $0.13 \pm 0.01 \cdot 10^{6}$. In drones of $A$ dorsata ( $\mathrm{n}=5$ ) it was $2.46 \pm$ $0.15 \cdot 10^{6}$ spermatozoa (table l).

\section{Spermatheca}

All spermathecae were surrounded by a dense tracheal net and had a spermathecal gland similar in shape to that of $A$ mellifera. The diameter of the spermathecae in both queens of $A$ andreniformis was 0.8 $\mathrm{mm}$. Because the spermathecal wall, as in all Apis species, is very thin, the volume of the spermatheca can be calculated directly from the diameter. It is $0.27 \mathrm{~mm}^{3}$ in $A$ andreniformis. The numbers of spermatozoa were 0.98 and $1.09 \cdot 10^{6}$. The diameter of the spermathecae of $2 A$ dorsata queens was $1.1 \mathrm{~mm}$ (volume: $0.7 \mathrm{~mm}^{3}$ ). The sperm number was 3.69 and $3.64 \cdot 10^{6}$ (table II).

\section{Ovarioles}

Two queens of $\boldsymbol{A}$ andreniformis had 100 and 104 ovarioles ( 50 and 52 per ovary respectively), the $2 A$ dorsata queens had 230 and 236 ovarioles.

Table I. Sperm numbers of vesiculae seminales $\left(x 10^{6}\right)$.

* (Koeniger et al, 1989)

\section{A andreniformis A florea * Adorsata}

$\begin{array}{lll}0.12 & 0.45 & 2.24 \\ 0.13 & 0.46 & 2.56 \\ 0.14 & 0.40 & 2.46 \\ 0.12 & 0.39 & 2.44 \\ 0.13 & 0.48 & 2.64 \\ & 0.45 & \\ & 0.41 & \end{array}$

$$
\begin{array}{lll}
\bar{x}=0.13 & \bar{x}=0.43 & \bar{x}=2.46 \\
s= \pm 0.01 & s= \pm 0.03 & s= \pm 0.15
\end{array}
$$


Table II. Data of spermathecae of $A$ andreniformis, $A$ florea, $A$ dorsata, $A$ mellifera and $A$ cerana.

* (Koeniger et al, 1989), "* (Woyke, 1966), "** (Woyke, 1975).

\begin{tabular}{|c|c|c|c|c|}
\hline & Diameter $(\mathrm{mm})$ & Volume $\left(\mathrm{mm}^{3}\right)$ & No sperm $\left(10^{6}\right)$ & Concentr $\left(10^{6} / \mathrm{mm}^{3}\right)$ \\
\hline$A a$ & $\begin{array}{l}0.8 \\
0.8\end{array}$ & $\begin{array}{l}0.27 \\
0.27\end{array}$ & $\begin{array}{l}1.09 \\
0.98\end{array}$ & $\begin{array}{l}4.03 \\
3.63\end{array}$ \\
\hline$A d$ & $\begin{array}{l}1.1 \\
1.1\end{array}$ & $\begin{array}{l}0.70 \\
0.70\end{array}$ & $\begin{array}{l}3.64 \\
3.69\end{array}$ & $\begin{array}{l}5.20 \\
5.27\end{array}$ \\
\hline$A f^{*}$ & $\begin{array}{l}0.8 \\
0.8 \\
0.8 \\
0.8 \\
0.75\end{array}$ & $\begin{array}{l}0.27 \\
0.27 \\
0.27 \\
0.27 \\
0.22\end{array}$ & $\begin{array}{l}1.35 \\
1.20 \\
1.20 \\
1.17 \\
0.85\end{array}$ & $\begin{array}{l}5.00 \\
4.44 \\
4.44 \\
4.33 \\
3.86\end{array}$ \\
\hline$A m^{* *}$ & 1.14 & 0.78 & 4.73 & 6.12 \\
\hline$A C^{* * *}$ & 0.98 & 0.48 & 1.35 & 2.79 \\
\hline
\end{tabular}

\section{DISCUSSION}

In the species $A$ dorsata and $A$ andreniformis, the numbers of spermatozoa in the spermatheca exceeded those of the seminal vesicles of the respective drones. This verifies multiple mating for both species. Now multiple mating has been found in all known Apis species except $A$ koschevnikovi where no data are yet available. Thus, polyandry appears to be a general feature of the Apis genus.

In $A$ mellifera and $A$ cerana, the number of matings cannot be deduced from the relation of the number of spermatozoa in the vesiculae seminales and in the spermatheca, because, in these species, drones inject the sperm into the oviducts while finally in the spermatheca less than $5 \%$ of the spermatozoa received during mating is stored.

In contrast to these results, no spermatozoa were found in the oviducts of freshly mated $A$ florea queens; they were found only in the spermatheca (Koeniger et al, 1989). The endophallus does not end in a bulb as in $A$ mellifera and $A$ cerana but in a thin tip (Simpson, 1960; Ruttner, 1988), which seems to be an adaptation for direct sperm transfer into the spermatheca.

In $A$ andreniformis the endophallus has a similar shape as in $A$ florea and also ends in a thin tip (Wongsiri et al, 1990). Supposing that, in $A$ andreniformis, the endophallus also enables direct sperm transfer, the number of matings would be 7-8. If the spermatozoa first reach the oviducts and the queen discards a lot of it, as in $A$ cerana and $A$ mellifera, a much higher number of matings can be assumed.

In Apis dorsata the size of the bulb is reduced and the cervix elongated compared to $A$ mellifera and $A$ cerana (Simpson, 1970; McEvoy and Underwood, 1988). There is no evidence to suggest that sperm is first injected into the oviducts or if a direct sperm transfer into the spermathe- 
ca exists. In the case of direct sperm transfer, 2 drones are required to fill the spermatheca. If sperm transfer occurs as in $A$ cerana, the number of matings would probably be much higher.

Sperm numbers in drones of $A$ florea and $A$ andreniformis are significantly different (table I; $t$-test, $P>0.001$ ). This result also supports the view that these should be considered as different species.

The high number of ovarioles in queens of $A$ dorsata suggests that she produces more eggs than the other 2 species ( 230 ovarioles compared with about 100). In queens from the Philippines, even more ovarioles per bee (260) were reported (Velthuis et al, 1971). Also the number of 3.7.106 spermatozoa, which is 3 times higher than in $A$ florea and $A$ andreniformis, supports this idea.

The concentrations of spermatozoa within the spermatheca appear to be similar in all Apis species, on average between 3 and $6 \cdot 10^{6} / \mathrm{mm}^{3}$ (table II). The lowest value was found in $A$ cerana (Woyke, 1975) with an average of $2.79 \cdot 10^{6}$ spermatozoa per $1 \mathrm{~mm}^{3}$ (13 queens) and highest in $A$ mellifera (Woyke, 1966) with 6.12.106 spermatozoa per $1 \mathrm{~mm}^{3}$ on the average (126 queens).

The anatomy of the spermathecae is similar in all Apis species. They all are surrounded by a dense tracheal net and have a spermathecal gland as described for $A$ mellifera by Snodgrass (1956). This may indicate that the mechanism of sperm storage and utilisation is similar in all species.

\section{ACKNOWLEDGMENTS}

We thank NA Zainal and RC Hindurangala for their valuable assistance in locating and catching the wild colonies.

GW Otis received a Research Leave Grant from the University of Guelph, and funds from the International Development Research Centre of Canada.

Résumé - Le nombre de spermatozoïdes chez les reines et les mâles, preuve d'accouplement multiple des reines chez Apis andreniformis et Apis dorsata. Chez Apis dorsata, nous avons trouvé une moyenne de $2,46 \cdot 10^{6}$ spermatozoïdes dans les vésicules séminales des mâles et $3,67 \cdot 10^{6}$ de spermatozoïdes dans la spermathèque de 2 reines; chez les mâles d'Apis andreniformis, 0,13.106 de spermatozoïdes et chez les 2 reines examinées 0,98 et $1,09 \cdot 10^{6}$ (tableaux $I$ et II). Le nombre de spermatozoïdes contenu dans la spermathèque des reines des 2 espèces est donc supérieur à celui produit par un seul mâle de chaque espèce. Ceci n'est possible que si les reines s'accouplent avec plusieurs mâles. Les reines d' $A$ dorsata doivent s'accoupler avec au moins 2 mâles. Et si, lors de l'accouplement, comme c'est le cas chez $A$ mellifica et $A$ cerana, le sperme passe dans les oviductes et que seule une petite partie atteint ensuite la spermathèque, le nombre d'accouplement doit être sensiblement plus élevé.

Chez $A$ florea, les spermatozoïdes passent directement dans la spermathèque. L'endophallus se termine par une pointe, et non par un bulbe, ce qui est considéré comme une adaptation au transfert direct (Koeniger et al, 1989). L'endophallus d'A andreniformis se termine également par une pointe (Wongsiri et al, 1990). C'est pourquoi nous admettons un transfert direct dans la spermathèque chez $A$ andreniformis également. Dans ce cas les reines doivent s'accoupler avec 7-8 mâles. Nous avons donc une preuve de l'accouplement multiple des reines chez toutes les espèces récentes d'Apis, à l'exception d' $A$ koschevnikovi, chez laquelle aucun comptage de spermatozoïdes n'a été effectué. 
Les reines d' $A$ dorsata renferment dans leur spermathèque presque 4 fois plus de spermatozoïdes que celles d' $A$ andreniformis. Les concentrations par $\mathrm{mm} 3$ sont par contre semblables $\left(5,2 \cdot 10^{6}\right.$ et $3,8 \cdot 10^{6}$, tableau If). La structure de la spermathèque est semblable chez toutes les espèces; c'est. la taille qui diffère. Les spermathèques sont toutes entourées d'un réseau dense de trachées et possèdent toutes une glande spermathécale bifide (Snodgrass, 1956). II en résulte vraisemblablement un stockage et une utilisation des spermatozoïdes pour la fécondation des œufs qui sont semblables chez toutes les espèces d'Apis.

\section{Accouplement multiple / spermatozoïde / Apis andreniformis / Apis dorsata}

\section{Zusammenfassung - Die Anzahl Sper-} matozoen in Königinnen und Drohnen beweist eine Mehrfachpaarung der Königinnen bei Apis andreniformis und Apis dorsata. Bei Drohnen von Apis dorsata fanden wir im Durchschnitt 2,46.106 Spermatozoen in den Vesiculae seminales; zwei Königinnen hatten je 3,67•106 Spermatozoen in ihren Spermatheken. Bei Drohnen von Apis andreniformis wurden $0,13 \cdot 10^{6}$ Spermatozoen gezählt, bei den beiden Königinnen 0,98 und 1,09-106 (Tabelle I, und II). Die Spermatheken der beiden Honigbienenarten enthielten demnach mehr Spermatozoen, als ein einzelner Drohn der jeweiligen Art produziert. Das ist nur möglich, wenn sich die Königinnen mit mehreren Drohnen paaren. Die A dorsataKöniginnen müssen sich mit mindestens 2 Drohnen gepaart haben. Sollten jedoch die Spermien bei der Paarung wie bei $A$ mellifera und $A$ cerana zunächst in die Ovidukte übertragen werden, von denen nur ein kleiner Teil in die Spermatheka gelangt, muß die Anzahl der Paarungen wesentlich höher sein.
Bei $A$ florea werden die Spermatozoen direkt in die Spermatheka übertragen. Der spitz auslaufende Bulbus des Endophallus wird als eine Anpassung an diese Funktion gedeutet (Koeniger et al, 1989). Der Endophallus von $A$ adreniformis endet ebenfalls mit einer Spitze (Wongsiri et al, 1990). Deshalb nehmen wir auch bei $A$ andreniformis eine direkte Spermaübertragung in die Spermatheka an. In diesem Fall sind die Königinnen von 7-8 Drohnen begattet worden.

Damit ist für alle rezenten Apis Arten mit Ausnahme von $A$ koschevnikovi, über die bisher keine Spermazählungen vorliegen - eine Mehrfachpaarung der Königinnen nachgewiesen. Die $A$ dorsataKöniginnen enthalten fast viermal so viel Spermatozoen in den Spermatheken wie die Koniginnen von $A$ andreniformis. Die Konzentrationen pro $\mathrm{mm}^{3}$ dagegen sind ähnlich $\left(5,2 \cdot 10^{6}\right.$ bzw 3,8・106, Tabelle II). Der Bau der Spermatheka differiert vor allem in der Größe, sonst sind sie ähnlich wie in $A$ mellifera von einem dichten Tracheennetz umhüllt und haben eine zweiarmige Spermathekaldrüse (Snodgrass, 1956). Wahrscheinlich erfolgt die Speicherung der Spermatozoen und deren Aktivierung zur Eibefruchtung in allen Apis Arten nach einem ähnlichen Prinzip.

\section{Mehrfachpaarung / Spermatozoon / Apis andreniformis / Apis dorsata}

\section{REFERENCES}

Koeniger N, Koeniger G, Wongsiri S (1989) Mating and sperm transfer in Apis florea. Apidologie 20, 413-418

McEvoy M, Underwood BA (1988) The drone and species status of the Himalayan honey bee, Apis laboriosa (Hymenoptera, Apidae). $J$ Kans Entomol Soc 61, 246-249

Ruttner F (1988) Biogeography and Taxonomy of Honeybees. Springer Verlag Berlin, 85-86 
Simpson J (1960) Male genitalia of Apis species. Nature 185, 56

Simpson J (1970) The male genitalia of Apis dorsata (F) (Hymenoptera, Apidae). Proc $R$ Entomol Soc Lond A 45, 169-171

Snodgrass RE (1956) Anatomy of the honey bee. Cornell University Press Ltd, Ithaca and London, $305 \mathrm{p}$

Tryasko VV (1956) Multiple mating of queen bees. Pchelovodstvo 33, 50-54 (in Russian)

Velthuis HHW, Clement J, Morse RA, Laigo FM (1971) The ovaries of Apis dorsata workers and queens from the Philippines. J Apic Res 10, 63-66

Wongsiri $S$, Limbipichai $K$, Tangkanasing $P$, Mardan M, Rinderer T, Sylvester HA, Koeni- ger G, Otis G (1990) Evidence of reproductive isolation confirms that Apis andreniformis (Smith 1858) is a separate species from sympatric Apis florea (Fabricius 1787). Apidologie 21, 47-52

Woyke $J(1960)$ Natural and artifical insemination of queen honeybees. Pszczel Zesz Nauk 4, 183-275 (English summary in Bee World, 1962, 43, 21-25)

Woyke J (1966) Wovon hängt die Zahl der Spermien in der Samenblase der auf natürlichem Wege begatteten Königin ab ? Z Bienenforsch 8, 236-247

Woyke $J$ (1975) Natural and artifical insemination of Apis cerana in India. J Apic Res 14, 153-159 